\title{
EL CINE Y LA CELEBRACIÓN DE LA NACIÓN VASCA. LAS FILMACIONES DEL ABERRI EGUNA DURANTE LA II REPÚBLICA
}

\author{
CINEMA AND CELEBRATION OF THE BASQUE NATION: \\ THE ABERRI EGUNA DURING THE SPANISH \\ SECOND REPUBLIC
}

\author{
Andoni Elezcano Roqueñi \\ $\mathrm{UPV} / \mathrm{EHU}$
}

Entregado el 6-2-2013 y aceptado el 26-6-2013.

Resumen: En este artículo se analizan las filmaciones de las cuatro primeras ediciones del Aberri Eguna (Día de la Patria Vasca), celebradas en Bilbao en 1932, San Sebastián en 1933, Vitoria en 1934, y Pamplona en 1935. De este modo es posible conocer las iniciativas cinematográficas llevadas a cabo durante la II República por el Partido Nacionalista Vasco (PNV) y la evolución de esta festividad nacionalista en sus vertientes rituales, simbólicas, organizativas y políticas. El análisis de estas películas permite profundizar en el modo en el que el PNV empleó el cine y esta celebración para unir a la comunidad nacionalista en torno no sólo a unas ideas sino también a unos símbolos. Esta misma fiesta se convirtió rápidamente en un importante símbolo nacionalista vasco y actuó a su vez como catalizador de nuevas construcciones simbólicas. Las fuentes cinematográficas se emplean aquí por vez primera también para conocer más a fondo la historia del PNV, su organización y su liderazgo en la década de 1930.

Palabras clave: Nacionalismo vasco, Segunda República, Aberri Eguna, Cine, símbolos.

Abstract: In this paper we analyze the shooting of the first four edition of the Aberri Eguna (The Day of the Basque Homeland), which took place in Bilbao in 1932, in San Sebastian in 1933, in Vitoria in 1934, and in Pamplona 
in 1935. In this way it is possible to study the cinematographic initiatives undertaken by the Basque Nationalist Party (PNV) during the Second Spanish Republic; and the evolution of this nationalist festivity, through its ritual, symbolic, organizational and political outlook. The analysis of these films is useful to delve on the way in which the PNV used cinema and this festivity to embody the abstract idea of the nationalist community, a festivity that quickly became an important symbol for the Basque nationalism and a catalyst for quite a lot of other symbols. These films are also a new source in the study of the very history of the PNV, its organization an its leadership in the thirties.

Key words: Basque Nationalism, Spanish Second Republic, Aberri Eguna, Cinema, symbols. 


\section{Introducción $^{1}$}

Como todos los rituales, las celebraciones comunitarias y las manifestaciones políticas, entendidas como un conjunto de prácticas simbólicas repetitivas y socialmente estandarizadas, han tenido una importancia crucial a la hora de forjar identidades colectivas y marcar las pautas de actuación de una determinada comunidad ideológica. Han sido y son la expresión pública de un colectivo, con la pretensión de influir política, social y/o culturalmente sobre el poder y la opinión pública y, especialmente, sobre los propios participantes en dichos rituales. Así, las fiestas y concentraciones de seguidores de cualquier nacionalismo tratan de exteriorizar en el espacio público la propia «comunidad imaginada». Ayudan con ello a la construcción de esa comunidad, en cuanto se aumentan los lazos de solidaridad entre personas que comparten sentimientos similares y les permite encarar con más fuerza las amenazas que pudieran acecharles ${ }^{2}$.

No obstante, sería difícil entender una celebración comunitaria sin atender al mismo valor simbólico que en sí misma representa, especialmente si - como sucede en el caso de las Fiestas nacionales o Días de la Patria - se repite anualmente en fechas determinadas. Estas fiestas son, además, catalizadoras de otros símbolos que las llenan de contenido. En este sentido, entendemos un símbolo como una herramienta mnemónica básica de cualquier ideología, es decir, como una «condensación mediática de ideologías» ${ }^{3}$, el cual, llevado al plano de lo político, tendría como

${ }^{1}$ Este artículo es la ampliación de la comunicación presentada al I Congreso Internacional «La Celebración de la Nación. Símbolos, mitos y lugares de memoria en el discurso nacional», celebrado en Vitoria-Gasteiz el 27 de octubre de 2011. Del mismo modo, forma parte de un proyecto de investigación subvencionado por la Secretaría de Estado de Investigación, Desarrollo e Innovación (HAR2011-24387), en el marco de un Grupo de Investigación de la Universidad del País Vasco (GIU 11/21). Por último, quisiera agradecer a José Luis de la Granja y, particularmente, a Santiago de Pablo, las informaciones y sugerencias aportadas para la realización de esta investigación, así como a la Fundación Sabino Arana Fundazioa y la Euskadiko Filmategia-Filmoteca Vasca, cuyos fondos han resultado imprescindibles para su realización.

2 Jesús Casquete, «Manifestaciones e identidad colectiva», Revista Internacional de Sociología, n. ${ }^{\circ}$ 42, septiembre-diciembre de 2005, pp. 101-125. Sobre el concepto de «comunidad imaginada», véase la obra clásica de Benedict Anderson, Imagined Communities. Reflections on the Origins and Spread of Nationalism, Verso, Londres, 1991.

${ }^{3}$ Gottfried Korf, «History of Symbols as Social History? Ten Preliminary Notes on the Image and Sign Systems of Social Movements in Germany», International Review of Social History, n. ${ }^{\circ} 38,1993$, p. 124. 
función «facilitar y promover una cierta lectura del mundo y agitar las emociones más profundas de aquellos entre los que el símbolo encuentra resonancia», al mismo tiempo que «los símbolos incitan a la acción» ${ }^{4}$. Así pues, las fiestas, concentraciones y manifestaciones se convierten en un laboratorio privilegiado para acercarse al universo ideológico y simbólico de cualquier movimiento político y social.

En el caso del nacionalismo vasco, la más importante manifestación pública, concentración política y celebración festiva comunitaria a lo largo de su historia ha sido el Aberri Eguna (Día de la Patria Vasca). Iniciada su andadura en Bilbao el Domingo de Resurrección de 1932, se ha venido celebrando de forma anual hasta nuestros días y constituye una de las fechas clave del calendario ritual nacionalista vasco. El cine, testigo de excepción de muchos de los eventos más importantes del siglo XX y notable constructor de imaginarios colectivos, también ha prestado atención al Día de la Patria Vasca. De hecho, los cuatro primeros Aberri Eguna durante la República (Bilbao, 1932; San Sebastián, 1933; Vitoria, 1934; y Pamplona, 1935) fueron recogidos por el cinematógrafo, conservándose a día de hoy todas las películas salvo la de la capital guipuzcoana, cuya filmación está sin embargo bastante documentada 5 .

En la presente investigación queremos acercarnos a la forma en que esos primeros Aberri Eguna fueron recogidos por el cine, fundamentalmente desde dos puntos de vista interrelacionados entre sí y que serán desarrollados de forma paralela: por una parte, analizar las imágenes mostradas del Aberri Eguna, las cuales nos dicen mucho acerca de desarrollo de cada una de las fiestas y de su evolución, prestando atención a las coberturas simbólicas, rituales y políticas que en ellas operan; $y$, por otro lado, examinar la forma en que los diferentes realizadores de las películas quisieron contar, a través del cine, su visión de dicha festividad, donde juegan un papel importantísimo los condicionamientos logísticos, ideológicos, políticos e históricos que motivaron la filmación de dichas películas en general, así como de ciertas tomas en particular. En ambos casos, se presenta ante nuestros ojos la forma en la que el PNV y sus bases construían su «partido-comunidad», así como el modo en que querían contarlo a través del cine. Dado el espacio de que dispo-

\footnotetext{
4 Jesús Casquete, En el nombre de Euskal Herria. La religión política del nacionalismo vasco radical, Tecnos, Madrid, 2009, p. 36.

5 Santos Zunzunegui, Euzkadi. Un film de Teodoro Ernandorena 1933-1983, Certamen Internacional de Cine Documental y Cortometraje de Bilbao, Bilbao, 1983.
} 
nemos, no pretendemos desentrañar aquí en profundidad el significado de cada sujeto simbólico mostrado en los filmes, pues esa labor ya ha sido realizada exhaustivamente por otros investigadores ${ }^{6}$, sino comprender la razón y el modo en el que estas filmaciones recogen y transmiten dichos símbolos.

\section{La invención de una tradición}

El Aberri Eguna ${ }^{7}$, fue una creación bastante tardía dentro del mundo simbólico-ritual del nacionalismo vasco. Desde que Sabino Arana fundara el Partido Nacionalista Vasco (PNV) en 1895 y, con ello, el propio movimiento nacionalista, hubo que esperar treinta y siete años para que este creara su propio Día de la Patria. La fecha elegida por el PNV (que por entonces monopolizaba casi por completo el movimiento nacionalista) para realizar la primera gran fiesta patriótica del nacionalismo vasco fue el Domingo de Pascua de Resurrección de 1932. La elección de esta fecha fue un claro exponente del predominio de la doctrina sabiniana en el PNV y de la mitificación sacralizada de Arana, desde su muerte en 1903.

En efecto, la historia del PNV desde su creación en 1895 ha estado íntimamente ligada a la figura de su fundador, Sabino Arana, a nivel ideológico y sobre todo en lo simbólico y ritual. La ideología aranista era un «nacionalismo de raíz tradicionalista e integrista, antiliberal y antiespañol, antisocialista y antiindustrialista. La religión católica y la raza vasca constituyen los dos pilares fundamentales de su concepción esencialista de nación vasca, a la cual bautiza con su neologismo Euzkadi (pueblo de raza vasca), en lugar del nombre tradicional de Euskalerria (pueblo que habla euskera). Su proyecto político de

${ }^{6}$ Para acercarse con más profundidad al universo simbólico del nacionalismo vasco, véase Santiago de Pablo, José Luis de la Granja, Ludger Mees y Jesús Casquete (coords.), Diccionario ilustrado de símbolos del nacionalismo vasco, Tecnos, Madrid, 2012.

7 Para el origen y la evolución del Aberri Eguna nos basamos en José Luis de la Granja, «El culto a Sabino Arana: la doble resurrección y el origen histórico del Aberri Eguna en la II República», Historia y Política, n. ${ }^{\circ}$ 15, 2006, pp. 69, y José Luis de la Granja y Jesús Casquete, «Aberri Eguna», en Santiago de Pablo et al., op. cit., 2012, pp. 33-56. Sobre la historia del PNV, véase Santiago de Pablo, Ludger Mees, José Antonio Rodríguez Ranz, El péndulo patriótico. Historia del Partido Nacionalista Vasco, Crítica, Barcelona, 1999-2001. 
Euzkadi sería un Estado vasco confederal basado en la unidad de raza y la unidad católica» ${ }^{8}$. Arana interpretaba la historia como una secular lucha de la nación vasca por su independencia y consideraba a los fueros como códigos de soberanía del pueblo vasco. Su lema, JEL (JaunGoikua eta Lagi-Zarra, Dios y Ley Vieja) sintetizaba la doctrina político-religiosa de Arana, por lo que sus seguidores fueron llamados jelkides (afiliado) o jeltzales (simpatizantes). Pese a la paulatina moderación política del PNV en la práctica (iniciada ya durante los últimos años de vida de su fundador), los principios aranistas del partido continuaron inmutables hasta los años treinta y la figura de Sabino Arana fue mitificada y santificada, celebrándose desde entonces todo tipo de efemérides de su vida política y personal ${ }^{9}$.

Así pues, se comprende por qué el PNV escogió la conmemoración de un episodio de la vida de su fundador para celebrar el Aberri Eguna. Se trataba de una mítica conversación mantenida en 1882 (aunque se desconoce su fecha exacta ${ }^{10}$ ) entre Sabino Arana y su hermano Luis, en la que este revelaría a aquel que su patria no era España, sino Vizcaya, que años más tarde sería sustituida por Euzkadi. Aprovechando que en 1932 se cumplirían las bodas de oro de aquella conversión, se tomó la decisión de celebrar el primer Aberri Eguna este año y de declarar aquel como «año sabiniano», iniciando importantes labores de «apostolado sabiniano» durante el mismo. Tras barajarse varias fechas, finalmente se eligió su celebración el Día de Pascua de aquel año, pues en ella se podría celebrar una doble resurrección, la de Jesucristo y la de la patria vasca, al conmemorar su presunto descubrimiento por Sabino Arana en 1882. Ello ayudaba a dar un carácter religioso al Aberri Eguna, en consonancia con la confesionalidad del PNV. De esta forma, más que una fiesta nacionalista vasca, el Aberri Eguna fue al principio una fiesta del $\mathrm{PNV}$, pues el carácter expresamente aranista y confesional de la misma impedía que el partido nacionalista heterodoxo Acción Nacionalista Vasca (ANV) - escisión a la izquierda del PNV en 1930 de ideología

${ }^{8}$ Santiago de Pablo y José Luis de la Granja, «Nueva documentación sobre el primer nacionalismo vasco: Correspondencia inédita de Sabino Arana con Luis de Elizalde (1900-1902)», Sancho el sabio, n. ${ }^{\circ} 31$, p. 254. Véase Javier Corcuera, La patria de los vascos. Orígenes, ideología y organización del primer nacionalismo vasco (1876-1903), Taurus, Madrid, 2001 (2. ${ }^{\text {a }}$ ed; primera de 1979).

9 José Luis de la Granja, op. cit., 2006.

${ }^{10}$ Ibidem. 
no aranista, aconfesional, republicana y autonomista $-{ }^{11}$ pudiera sumarse a la celebración, aunque ANV toleró que sus afiliados asistieran a título personal. Desde entonces hasta nuestros días se ha venido celebrando anualmente el Aberri Eguna, aunque la historia de esta fiesta (hoy de todo el nacionalismo y no sólo del PNV) ha cambiado mucho desde entonces ${ }^{12}$.

\section{Nuevos rumbos proselitistas}

Desde su fundación, el PNV experimentó un paulatino proceso de expansión política, social y territorial por la Vasconia peninsular (fundamentalmente Vizcaya y Guipúzcoa y, más lentamente, Álava y Navarra). Paralelamente, la estructura organizativa del partido y sus instrumentos de propaganda se fueron ensanchando y complejizando. Como «partido de vocación totalizadora» que era, «todo era susceptible de ser transformado en apoyo del ideal sabiniano» ${ }^{13}$ : manifestaciones y mítines en todo tipo de eventos, libros, folletos, prensa periódica, obras de teatro, actos folclóricos, excursiones montañeras, etc. Sin embargo, cuando comenzó la II República, apenas se había profundizado en el uso del cine, uno de los medios que desde hacía tiempo había venido revolucionando ya no sólo las comunicaciones, sino el ocio y los imaginarios colectivos ${ }^{14}$.

En España el PNV fue uno de los partidos que más impulsó el cine como medio de propaganda ${ }^{15}$, al ser un modo eficaz de llegar a todas las capas de la población, de la que todavía el $14 \%$ era analfabeta ${ }^{16}$ : «Lo que para los intelectuales viene a ser el libro es para la masa popular la cinta cinematográfica. Es el "cine" el libro donde el pueblo lee», se afirmó en

11 José Luis de la Granja Sainz y Gaizka Fernández Sodevilla, «Los nacionalistas heterodoxos en la Euskadi del siglo XX», Alcores, n. ${ }^{\circ} 13$, pp. 165-186.

12 Luis de la Granja y Jesús Casquete, op. cit.

13 José María Tápiz, El PNV durante la II República: organización interna, implantación territorial y bases sociales, Fundación Sabino Arana-Sabino Arana Kultur Elkargoa, Bilbao, 2001, p. 390.

14 Ibidem, pp. 297-385. Vase Santiago de Pablo, The Basque Nation On-Screen. Cinema, Nationalism, and Political Violence, Center for Basque Studies, Reno, 2012.

15 Ibidem, pp. 334-338.

16 José Luis de la Granja y Santiago de Pablo (eds.), Historia del País Vasco y Navarra en el siglo Xx, Biblioteca Nueva, Madrid, 2009 (1. a ed., 2002), p. 333. 
el diario nacionalista El Día en $1933^{17}$. Por su parte, el sacerdote e ideólogo nacionalista José Ariztimuño (Aitzol), fascinado con el eficaz partido que los nazis estaban sacando de la industria cinematográfica al servicio del ideal patriótico, afirmó que «algo de eso lleva también hecho el patriotismo vasco». En este contexto, reflexionaba sobre «lo que puede ser el cine como medio de propaganda patriótica [...], entre nosotros y los vascos esparcidos por el mundo» ${ }^{18}$. El también ideólogo nacionalista $\mathrm{Fe}-$ derico Belausteguigoitia advirtió en 1936 de que el cine, ya sonoro en su mayoría, «se ha puesto al alcance de las familias y círculos con pequeños aparatos que pueden llenar un gran papel» como medio para la difusión del euskera ${ }^{19}$.

De este modo, durante la República el PNV impulsó de forma más o menos directa la filmación de los Aberri Eguna de Bilbao (1932), San Sebastián (1933) y Vitoria (1934). El de Pamplona de 1935 lo filmaría un jelkide aficionado al cine, Agustín Ugartechea, como parte de sus películas domésticas. Estas cuatro filmaciones constituyen el eje sobre el que gira la presente investigación. Las de Bilbao, Vitoria y Pamplona son cortometrajes sin sonido y se han conservado hasta nuestros días. Por el contrario, la de San Sebastián, recogida en el largometraje documental sonoro Euzkadi, no se conserva (víctima, presuntamente, de su destrucción en 1937 tras la toma de San Sebastián por los franquistas ${ }^{20}$ ), aunque nos ha llegado bastante documentación sobre ella, pudiendo realizarse una somera reconstrucción.

\section{Aberri Eguna en Bilbao (anónimo, 1932)}

El propio motivo de la festividad del Aberri Eguna justificaba por sí solo la celebración de la misma en Bilbao, pues algunos espacios de la capital vizcaína fueron convertidos en lugares de memoria para los jeltzales. Fue aquí donde nació Sabino Arana (concretamente en Abando, anteiglesia anexionada por Bilbao a finales del siglo XIX), cuya casa, la Casa de Albia, en la que nació y donde se produjo su «revelación» naciona-

\footnotetext{
17 El Día, 17-XII-1933, p. 1

18 Euzkadi, 29-XII-1933, p. 1.

19 P. Belauste'tar [F. Belausteguigoitia], Hacia una lucha verdad pro-euskera, Bilbao (ca. 1936), p. 20.

${ }^{20}$ Santos Zunzunegui, op. cit., 1983, p. 26.
} 
lista de 1882, iba a ser convertida en la sede central del PNV y «rebautizada» como Sabin Etxea (Casa de Sabino). Fue también en Bilbao donde Arana comenzó su andadura política y donde fundó el PNV, convirtiéndose desde sus orígenes en el principal foco de implantación del partido. Las fiestas y actos conmemorativos en torno al primer Aberri Eguna se desarrollaron a lo largo de tres días, comenzando el sábado 26 de marzo, día en el que, tras varios homenajes a Sabino Arana, fue inaugurada $\mathrm{Sa}$ bin Etxea como sede central del PNV. Al día siguiente, Domingo de Resurrección, se celebraron los actos centrales de la fiesta nacionalista: tras un gran desfile por la Gran Vía hasta Sabin Etxea, se izó en esta una gran ikurriña y se descubrió una placa que conmemoraba la efeméride de la «revelación» de 1882. Fue la mayor concentración nacionalista hasta el momento, a la que asistieron unas 65.000 personas según la prensa nacionalista, llegadas desde todos los rincones del territorio vasco. El lunes, último día de la fiesta, se celebraron varios actos folclóricos, así como un banquete en el casino de Archanda, para líderes y representantes de todas las organizaciones del PNV.

La película que recogió el primer Día de la Patria del nacionalismo vasco fue Aberri Eguna en Bilbao. Se trata de un documental mudo de 8 minutos de duración, rodado con una cámara de $35 \mathrm{~mm}$. Desconocemos quién fue el realizador de la misma, pero muy probablemente se trató de una iniciativa del PNV. La ausencia casi total de concesiones artísticas, técnicas (las imágenes se suceden de forma lineal sin ninguna labor de postproducción) y explicativas (carece de intertítulos), y su tardía proyección al público (en 1934), es prueba a nuestro juicio de que el filme tuvo la primitiva finalidad de ser simple testimonio documental del primer Día de la Patria, a la espera de que en un futuro pudiera ser empleado por la propaganda del partido, como así acabó resultando.

En el filme, la cámara va mostrando, de forma lineal, los principales acontecimientos del 27 de marzo de 1932, durante aquel primer Aberri Eguna, quedando sin filmar los actos festivos del día anterior y posterior. La cámara, situada en los alrededores del puente del Arenal, empieza mostrando cómo van llegando a Bilbao numerosos jeltzales (andando, en tren y en barco) y se van dirigiendo paulatinamente hacia Abando, donde se celebraría el acto central del día: el desfile nacionalista. Antes de filmar dicha marcha, el cameraman se detiene en Sabin Etxea, haciendo una panorámica de la misma. Posteriormente, durante varios minutos, la cámara, situada estratégicamente en la Plaza Elíptica, filma el desfile a su paso por la Gran Vía, por el que circulan numerosos dirigentes del PNV y cientos de nacionalistas 
adscritos a las diferentes organizaciones adheridas al partido, seguidos de la gran masa de simpatizantes, que cerró la marcha. La película finaliza con unas breves tomas de un desfile folclórico en un lugar indeterminado.

\section{El Aberri Eguna en San Sebastián y Euzkadi (Teodoro Hernandorena, 1933)}

Tras la primera celebración en Bilbao, el PNV organizó los tres siguientes Aberri Eguna de forma centralizada y rotatoria en las capitales vascas peninsulares. Así, el 16 de abril de 1933, coincidiendo con la celebración de la Semana Cultural Vasca, tocó su turno a San Sebastián, bajo el lema «Euzkadi-Europa», en la que se pretendía dar impulso a la proyección exterior del movimiento. A la concentración asistieron tanto importantes dirigentes del PNV (los diputados José Antonio Aguirre y Telesforo Monzón) como otros destacados líderes nacionalistas de otras regiones: el galleguista Ramón Otero Pedrayo, el catalanista Francesc Maspons i Anglasell y el estoniano Ewald Ammende (secretario del Congreso de Nacionalidades Europeas). En sus discursos se hizo apología del independentismo y de la solidaridad entre los pueblos de Europa. La concentración fue todo un éxito, a la que asistieron unas 60.000 personas llegadas de toda Vasconia ${ }^{21}$.

Euzkadi es la película en la que se integraron las imágenes de esta fiesta. De hecho, las primeras imágenes filmadas para Euzkadi fueron las de los actos «Euzkadi-Europa» con dos cámaras mudas de $35 \mathrm{~mm}$ manejadas por dos operadores catalanes, pensadas originalmente (como pasó con Aberri Eguna en Bilbao) para servir de documento de archivo sobre la fiesta. Fue posteriormente cuando Hernandorena pensó en emplear a los mismos operadores para filmar imágenes de las siete provincias vascas en general y de las actividades del movimiento nacionalista en particular, y sonorizándolo, convirtiéndose así en el film Euzkadi, de 90 minutos, siendo en el primer largometraje documental de propaganda de un partido político de España ${ }^{22}$. Por desgracia, de las películas que estamos estudiando, Euzkadi (también publicitada extraordinariamente como

21 Euzkadi, 18-IV-1933.

22 Santiago de Pablo, Tierra sin paz. Guerra civil, cine y propaganda en el País Vasco, Biblioteca Nueva, Madrid, 2006, p. 17. 
«Euzkadi-Europa» ${ }^{23}$ ) es la única copia que no se conserva. Destacar que Euzkadi fue íntegramente promovida y financiada por Hernandorena (que en el momento de la filmación era el líder de Euzko Gaztedi - Juventud Vasca - de San Sebastián), aunque el PNV sólo se vinculó a la misma al final, cuando el Gipuzko Buru Batzar (Consejo Regional de Guipúzcoa del PNV, del que pasó a ser presidente Hernandorena) financió la distribución de la película ${ }^{24}$.

Pese a la desaparición de la película, podemos reconstruir parcialmente cómo se reflejó el Aberri Eguna en el filme Euzkadi gracias a las críticas cinematográficas que realizaron los diarios nacionalistas Euzkadi y El Día y al testimonio de Hernandorena, recogido por Zunzunegui en $1983^{25}$. El documental comienza con la llegada de los numerosos vaporcitos desde todos los puntos de la costa vasca a la Bahía de la Concha, «llevando al frente el "Ayeta-Mendi", desde el que autoridades y excursionistas saludan conmovidas. El momento culmina al pasar la flotilla ante la cárcel de Ondarreta, saludando con sus sirenas a Idiakez ${ }^{26}$, preso nacional [...], el hombre que hoy representa el dolor de la raza y al que saludan con el sonar de sus sirenas, mientras se oyen los majestuosos compases del "Agur Jaunak", el canto del saludo oficial vasco» 27 . «Siguen después unas escenas a la salida de la solemne misa mayor celebrada en la iglesia de Santa María» ${ }^{28}$. Por último, recoge los actos más importantes del día, el gran acto «Euzkadi-Europa», celebrado en la campa de Atocha, donde se ven y escuchan «los discursos pronunciados por las distintas personalidades en sus respectivos idiomas» ${ }^{29}$ (fragmentos de los mítines de Aguirre, Amende, Hernandorena, Monzón, Maspons, etc.). «Muchos metros de la película están destinados al gran mitin Euzkadi-Europa $»^{30}$. Por último, «la cámara filma los planos del público en el frontón de rebote de Atocha ${ }^{31}$.

23 Euzkadi, 21-XII-1933, p. 1; 12-I-1934, p. 8.

${ }^{24}$ Santos Zunzunegui, op. cit., 1983; Santos Zunzunegui, El cine en el País Vasco, Diputación Foral de Vizcaya, Bilbao, 1985, pp. 118-124.

25 Santos Zunzunegui, op. cit., 1983.

${ }^{26}$ Los motivos de su encarcelamiento y la capitalización de su caso por el PNV son analizados en el apartado 7.

27 Euzkadi, 28-XII-1933, pp.1-2.

28 Euzkadi, 24-XII-1933, p. 3.

29 Euzkadi, 24-XII-1933, p. 3.

30 Euzkadi, 28-XII-1933, pp. 1-2.

31 Santos Zunzunegui, op. cit., 1983, p. 13. 


\section{Aberri Eguna en Gasteiz (Víctor Madinabeitia, 1934)}

La paralización en las Cortes españolas de la tramitación del proceso del Estatuto de autonomía del País Vasco, aduciendo la elevada abstención producida en Álava en el referéndum de noviembre de 1933, fue el motivo por el que el PNV subrayó la necesidad de celebrar el Aberri Eguna el 1 de abril de 1934 en Vitoria. Por vez primera, la fiesta iba a celebrarse en un lugar como Álava, donde el nacionalismo era una fuerza minoritaria, mientras que los carlistas eran predominantes. Así, para el PNV era decisivo hacer una demostración de fuerza en esta provincia, una tierra que consideraban que estaba en peligro, dada la debilidad del nacionalismo en la zona. Para ello fue aún más importante, si cabe, la gran convocatoria de nacionalistas de todo el País para la ocasión, a sabiendas de que los nacionalistas alaveses no podrían llenar las calles de Vitoria. La celebración fue otro éxito para el PNV, pues asistieron a la concentración entre 30 y 50.000 personas, la mayoría llegados de Vizcaya y Guipúzcoa ${ }^{32}$.

Aberri Eguna en Gasteiz (también conocida como Vistas del grandioso Aberri Eguna de Gazteiz ${ }^{33}$ o Vista del Aberri Eguna de Gasteiz ${ }^{34}$ ), realizada por Víctor Madinabeitia, continuó la tradición cinematográfica iniciada en $1932^{35}$. Es un cortometraje documental de 16:35 minutos de duración, filmado sin sonido con una cámara de $16 \mathrm{~mm}$. y producida por el Araba Buru Batzar (Consejo Regional de Álava del PNV).

La película muestra de forma sucesiva y sin ningún elemento explicativo los principales actos desarrollados el domingo 1 de abril. Arranca con la llegada de las masas nacionalistas a Vitoria en numerosos medios de transporte: coches, autobuses, bicicletas, motos, saliendo de la estación de trenes, etc. Son tantos los vehículos que llegan a Vitoria que se forma una caravana en una carretera que entra en la ciudad. Posteriormente muestra uno de los aparcamientos habilitados para absorber la gran masa de vehículos desplazados hasta el lugar. Después, se reproducen los actos musicales realizados en el quiosco de la Plaza de la República (actual Plaza de

32 Román Berriozabal, Aberri Eguna (Gasteiz 1934). ¡Euskadi entera está con Araba!, Arabera, Gasteiz, 2005.

33 Euzkadi, 6-V-1934, p. 8.

34 Santos Zunzunegui, op. cit., 1985, p. 121.

35 Las inquietudes cinematográficas del PNV también se observan en un breve anuncio en el diario Euzkadi (20-III-1934, p. 2) antes de la celebración del Aberri Eguna: «Cinematógrafo. Se admiten proposiciones para impresionar películas de los principales actos». 
España), en la que se ve el Zazpiak-bat y numerosas banderas que cuelgan de la balconada del batzoki (Centro Vasco), y más adelante pasa por el quiosco del parque de la Florida, donde hay un concierto de txistularis. Por último, y tras volver a pasar por la Plaza de la República, la cámara capta durante la mitad restante del filme los principales actos del día celebrados en el campo de fútbol de Mendizorroza. Aquí se puede ver en el palco y posando para la cámara a los diputados Juan Antonio Careaga, Telesforo Monzón y José Antonio Aguirre, seguidos de las actuaciones de gran cantidad de dantzaris y musikalaris llegados de toda la geografía vasca. Todas estas imágenes del filme se intercalan con muchas tomas que muestran la gran masa de nacionalistas que se desplaza por las calles de Vitoria, junto con otras más cercanas o «familiares» de los participantes.

\section{Aberri Eguna en Iruñea (Agustín Ugartechea, 1935)}

De los Aberri Eguna estudiados, el de Pamplona fue el que se desarrolló con más anormalidad. A la debilidad nacionalista en una Navarra de gran predominio carlista se le sumó una coyuntura extraordinariamente negativa. El ciclo represivo desencadenado tras la Revolución de Octubre de 1934 también afectó al PNV, que vio cómo la prolongación del estado de guerra-alarma impidió la celebración del Aberri Eguna el Día de Pascua el 21 de abril en Pamplona. Finalmente, las autoridades gubernativas permitieron su celebración el domingo 30 de junio, pero con una serie de medidas que encorsetaron su normal desenvolvimiento: se impidió que se denominara Día de la Patria o Aberri Eguna, por lo que el PNV decidió llamarlo Euzkadi Eguna; se limitó la celebración de los actos oficiales a lugares cerrados (el teatro, el frontón, la plaza de toros, etc.); se recomendó a los militantes y simpatizantes jeltzales que no dieran ninguna clase de gritos para evitar provocaciones; y se prohibió la exhibición de símbolos nacionalistas. El interés por parte del PNV, sabedor del escaso predicamento que su movimiento tenía en la mayor parte de Navarra y de la necesidad de evitar nuevos problemas con las autoridades, se centró en comunicar una y otra vez a sus afiliados la necesidad de cumplir estrictamente las normas impuestas por el gobernador ${ }^{36}$. Todo con el fin de demostrar la civilidad del PNV en una tierra que consideraban suya y evitar,

36 Euzkadi, 29 y 28-VI-1935. 
por tanto, el enfrentamiento con los navarros, a los que tomaban por compatriotas y a los que invitaron a sumarse a la fiesta. La asistencia se cifró entre las 12.500 (según los diarios de derechas) y las 40.000 personas (según las fuentes nacionalistas) ${ }^{37}$.

De todas las filmaciones que estamos analizando, Aberri Eguna en Iruñea (título de archivo atribuido por la Filmoteca Vasca) es la única que fue completamente amateur o doméstica, y no de tipo profesional o semiprofesional - aunque sospechamos que quizás pudo realizarse otra filmación paralela de este tipo ${ }^{38}-$. Esta película no fue descubierta hasta 2006 por el catedrático Santiago de Pablo, por lo que no aparece en los libros y catálogos publicados con anterioridad. El filme fue realizado por el jelkide bilbaíno Agustín Ugartechea, un aficionado al cine desconocido hasta hace poco, pese a que entre sus hitos cinematográficos se encuentra el haber realizado para el Gobierno de Euzkadi las primeras filmaciones de Guernica tras el bombardeo de $1937^{39}$. Su condición de afiliado y su más que posible trato cercano con los mandatarios del partido y organizadores de los Aberri Eguna, le permitió rodar algunos planos claramente privilegiados en la fiesta. De ocho minutos de duración y muda, la filmación se realizó con una cámara de $16 \mathrm{~mm}$.

Esta filmación nos muestra de forma continuada algunos de los hechos y actos más destacados de aquel domingo 30 de junio de 1935 en Pamplona con motivo del Euzkadi Eguna. Por la mañana se observa la entrada por el norte de la capital navarra, por la carretera de Irurzun (desde donde se bifurcaba hacia Bilbao y San Sebastián), de numerosos ciclistas, coches y autobuses repletos de nacionalistas procedentes de toda Vasconia a la fiesta patriótica, los cuales se dirigen a una de las grandes campas habilitadas como aparcamientos. Después, y durante la mayor parte de la filmación, la cámara recoge los principales actos del día celebrados en la plaza de toros. En este lugar, al mediodía, muestra de cerca (en un plano medio) los mítines pronunciados, en este orden, por los dirigentes nacionalistas Aguirre, Monzón y Manuel Irujo. Posteriormente, Agui-

37 Josu Chueca, El nacionalismo vasco en Navarra: 1931-1936, Universidad del País Vasco, Leioa, 1999, pp. 304-318.

${ }^{38}$ En junio de 1936 se proyectaron en Sabin Etxea unas imágenes de los cuatro primeros Aberri Eguna, entre las que parece poco probable que figurara la cinta amateur de Ugartechea. Esto nos hace pensar que el acto fue recogido también por un cameraman enviado por el PNV, cuya filmación no se habría conservado. Euzkadi, 7-VI-1936, p. 8.

39 Santiago de Pablo, op. cit., 2006, pp. 79-200. 
rre abre la entonación del Euzko Abendaren Ereserkia (himno del PNV creado por Sabino Arana a partir de una melodía tradicional ${ }^{40}$ ), al que le siguen el resto de dirigentes que le rodean y, con ellos, toda la plaza. Ya por la tarde, en el mismo lugar, se desarrollan numerosos actos folclóricos y pueden verse bertsolaris y muchos dantzaris que bailan las danzas típicas de diversas comarcas vascas. Entre estos actos, al final de un desfile de dantzaris se puede ver una ikurriña abanderada por uno de estos, siendo (por los motivos antes indicados) la única bandera abiertamente nacionalista que se observa en todo el filme. A lo largo de la filmación, Ugartechea intercala estas imágenes de los actos oficiales con otras de carácter más informal, como las de las personas que saludan desde el mirador de Larraina a los que entran a la ciudad por el norte desde la carretera de Irurzun, los planos conjuntos tomados en la calle de personas anónimas (posiblemente amigos de Ugartechea) y conocidas (Telesforo Monzón y Rafael Picavea, los cuales posan para la cámara), que se acercan a la plaza de toros, así como unos momentos de esparcimiento de unos nacionalistas a las afueras de la ciudad, al mediodía.

\section{La celebración de la nación en imágenes en movimiento}

Pese a las carencias expresivas y técnicas de la mayoría de las películas estudiadas, las cuatro cintas no sólo muestran cómo se desarrollaron los diferentes Aberri Eguna, con sus paralelismos y diferencias, sino también se convierten un buen testimonio de la propia organización interna y del imaginario del PNV de la época, plasmado fundamentalmente a través de sus símbolos. Asimismo, hay que tener en cuenta en todo momento el punto de vista de los cameraman, que habla de la importancia que para ellos tenían estos actos.

Así, antes de comenzar con el análisis de la películas, es necesario tener en cuenta la dificultad que existía en la década de 1930 para multiplicar las imágenes cinematográficas, tanto profesionales como amateur, en especial en un País Vasco donde no existía una industria cinematográfica. Frente a lo que sucedería más adelante (a partir de la generalización del cine en 8 y súper $8 \mathrm{~mm}$, de la videocámara doméstica y de las cadenas

40 Se convirtió además en himno oficial del Gobierno de Euzkadi en octubre de 1937 y del Gobierno Vasco en 1979. Leyre Arrieta Alberdi, «Himno Eusko Abendaren Ereserkia», en Santiago de Pablo et al., op. cit., 2012, pp. 482-488. 
de televisión), no se conservan excesivas imágenes de los años treinta en territorio vasco, en gran medida porque no llegaron a filmarse ${ }^{41}$. En este contexto, el mismo hecho de que todos los Aberri Eguna fueran filmados subraya la importancia que el PNV y algunos afiliados daban a esta fiesta. Y pese a que las filmaciones del Aberri Eguna son de escasa duración y limitada calidad técnica y artística, son quizás estas mismas carencias las que contribuyen a reforzar el valor documental de las mismas. La carestía del medio fílmico, la escasa operatividad de aquellas cámaras y el limitado despliegue técnico, en las que sólo se contó con una cámara para cada filmación (excepto en San Sebastián, donde fueron dos), imponía al realizador una consciente y premeditada labor de selección, en la que tendían a privilegiar los acontecimientos a su juicio importantes, dejando en un segundo plano o rechazando los considerados de menor entidad. De este modo, en estas filmaciones nos encontramos que se recogen tanto los actos oficiales más importantes del día como aquellos extraoficiales, que por el nivel de importancia que le es otorgado por los cameraman, nos dicen mucho acerca de lo que para ellos simbolizaba aquella festividad. Así pues, resulta de gran interés la mirada coincidente que, no por casualidad, muestran en temas clave los documentales «oficialistas» del PNV y el film amateur de Ugartechea.

Comenzando con el análisis, un elemento muy importante que es recogido expresamente y con notable interés en todas las películas es la peregrinación político-litúrgica que se dio en cada concentración, cargada, como se ha dicho, de notables connotaciones políticas y religiosas por los jeltzales. Concretamente, todas las películas comienzan con la llegada a cada ciudad de cientos de nacionalistas que se movilizaron para participar en cada festividad: se ven así llegar a El Arenal de Bilbao numerosas personas a la estación de La Naja en tren desde la margen izquierda y en vapores desde diversos puntos de la costa vasca (algunos desde Bermeo, importante feudo nacionalista) ${ }^{42}$; en San Sebastián la cámara filmó la legada de numerosos vaporcitos a la bahía, en los que van líderes y militantes peneuvistas; en Vitoria el cámara se detiene a filmar

${ }^{41}$ Sobre las escasas iniciativas cinematográficas realizadas en el País Vasco en la República, véase: Santos Zunzunegui, op. cit., 1985, pp. 111-127; y Josetxo Cerdán: «El cine sonoro y la Segunda República», en Santiago de Pablo (ed.): Los cineastas. Historia del cine en Euskal Herria, 1896-1998, Fundación Sancho el Sabio Fundazioa, Vitoria-Gasteiz, 1998, pp. 87-116.

${ }_{42}$ Aberri Eguna. El Día de la Patria, Verdes, Bilbao, 1932, p. 50. 
el exterior de la estación de trenes donde se concentran una gran cantidad de personas, así como el enorme número de coches y autobuses repletos de nacionalistas que llegan en tan grandes cantidades que forman una caravana en una de las entradas de la ciudad; y en Pamplona, se ven llegar también numerosos transportes que entran por el norte, por la carretera de Irurzun, principal vía de entrada de los nacionalistas (procedentes en su mayoría de Vizcaya y Guipúzcoa, donde eran más fuertes y numerosos $)^{43}$. Se trata de una representación gráfica del «pueblo en marcha» que, según José Antonio Aguirre, era el PNV, superando así la definición de un mero partido político ${ }^{44}$.

Son muchas las personas que desde diferentes lugares (casas, miradores, riberas, carreteras o aceras) reciben a los movilizados con saludos o agitando pañuelos, siendo respondidos por aquellos de igual forma. En esta línea, los pródigos, recíprocos y generalizados saludos mostrados por las cámaras (en ocasiones, de forma explícita) en las diversas películas, al calor del recibimiento de los nacionalistas movilizados, son un buen indicador del sentimiento de cohesión existente entre diversas personas con un importante sentido de pertenencia a una «comunidad imaginada» como la nacionalista, que les hace mostrar empatía entre ellos con independencia del mayor o menor conocimiento mutuo previo o de las diferencias existentes entre sus miembros: cultura, procedencia, género, edad, estatus económico y social, etc. Porque, como indicó B. Anderson: «Es imaginada porque aún los miembros de la nación más pequeña nunca llegarán a conocer a sus compatriotas, ni siquiera oír hablar de ellos; y sin embargo, la mente de cada uno alberga la imagen de su comunión ${ }^{45}$.

Junto a este sentido simbólico, las imágenes evidencian y quieren evidenciar tanto la gran capacidad movilizadora y organizadora del PNV como el notable apoyo popular del que gozaba. De hecho, en 1933 fue el partido más votado en el País Vasco, siendo sus mejores resultados electorales hasta esa fecha ${ }^{46}$. En los distintos Aberri Eguna estudiados se cuida-

43 Euzkadi, 2-VII-1935, p. 3.

44 José Antonio de Agirre y Lekube, Entre la libertad y la revolución 1930-1935. La verdad de un lustro en el País Vasco, Verdes Achirica, Bilbao, 1935, pp. 164-165.

45 Benedict Anderson, Imagined Communities. Reflections on the Origins and Spread of Nationalism, Verso, Londres, 1991, p. 6.

${ }^{46}$ La creciente fuerza del PNV, así como su distanciamiento de las derechas españolas tras el fracasado Estatuto de Estella, le llevó a convertirse en el tercer gran polo político en la denominada «triangulación política vasca». Véase: Juan Pablo Fusi, País vasco: pluralismo y nacionalidad, Alianza Editorial, Madrid, 1990 (1. ${ }^{a}$ edición 1984). 
ron enormemente los aspectos relacionados con el desplazamiento, para lo que se organizaron trenes y autobuses especiales, marchas de mendigoxales (jóvenes montañeros propagandistas, sobre los que volveremos), la llegada y aparcamiento de los vehículos (para los que se habilitaron grandes campas), etc. ${ }^{47}$. $\mathrm{Y}$ es que era necesario acudir en masa, para hacer una demostración de cohesión y fuerza, para reafirmar a los convencidos, atraer a los indecisos y prevenir a sus adversarios. De este modo, las concentraciones en Bilbao y San Sebastián fueron importantes tanto por tratarse de las primeras ediciones y como por el propio carácter simbólico que adquirieron para el nacionalismo (homenaje a su fundador en Bilbao y proyección exterior en San Sebastián). Pero no menos importantes fueron las ediciones de Vitoria y Pamplona, espacios reclamados por el nacionalismo vasco como parte de la patria vasca, pero donde el asentamiento nacionalista era problemático, visto incluso con hostilidad por los carlistas. De ahí que todas las filmaciones reflejen el interés de sus realizadores por recoger aquellas concentraciones.

Puede observarse así, complementando a lo dicho y mostrado por la prensa afín al PNV, la gran asistencia que se produjo con motivo de cada Aberri Eguna, donde los jeltzales asistentes abarrotaron tanto los espacios abiertos como los diversos recintos en los que se desarrollaron las diferentes celebraciones político-festivas. No obstante, esta gran afluencia puede contrastar con las imágenes tomadas por Ugartechea en la plaza de toros de Pamplona, en la que, mientras filma unos bailes folclóricos, se puede ver al fondo unas gradas casi completamente vacías. Esto no fue debido a la falta de asistencia (pues según otras imágenes de la plaza, tanto de Ugartechea como de la prensa nacionalista, se aprecia un lleno superior a tres cuartos) ni al desinterés de los que se marcharon, sino a la solana veraniega que pegaba en las gradas, que alejó a casi todos los que allí se encontraban hacía las zonas con sombra o fuera de la plaza. El «descuido» de Ugartechea al filmar estas gradas vacías ${ }^{48}$ nos permite reafirmar el carácter doméstico y no documental-propagandístico de esta filmación en el momento del rodaje ${ }^{49}$.

Otro tanto puede advertirse con las labores organizativas en las que tanto empeño se puso para gestionar correctamente la recepción y movili-

47 Esta organización se puede ver claramente en las tiradas de los periódicos nacionalistas en los días anteriores a cada celebración.

48 Detalle que, evidentemente, no es comentado ni mostrado por la prensa nacionalista.

49 Efrén Cuevas Álvarez (ed.), La casa abierta. El cine doméstico y sus reciclajes contemporáneos, Ayuntamiento de Madrid, 2010, pp. 39-60. 
dad de todos los desplazados y el buen desarrollo de todas las actividades. Para ello se crearon numerosas comisiones organizadoras a las que se presentaron muchos voluntarios. A lo largo de las películas pueden apreciarse algunos de estos aspectos, aunque los cameramen, más interesados en mostrar el desarrollo global de la festividad, no se detienen expresamente en ellos. Por ejemplo, en Vitoria y Pamplona se pueden ver a varios de estos organizando el tráfico, indicando la dirección a los vehículos y ciclistas que entran en la ciudad, para que se dirijan a los aparcamientos habilitados (que también son mostrados) o, en Vitoria, poniendo señalizaciones de papel en las lunas delanteras de los vehículos para su mejor identificación y organización. Tampoco hay que olvidar la importante tarea organizativa que desarrollaron los mendigoxales, a los que vemos en Bilbao vestidos de montañeros y armados con varas, realizando labores de apertura y cierre del desfile, de «escolta» y encauzamiento del mismo ${ }^{50}$.

Dentro de estas labores movilizadoreas y organizativas jugaron un papel fundamental las organizaciones paralelas del PNV, que son abundantemente recogidas por las cámaras de forma expresa o implícita. Es el caso de los citados mendigoxales, de Emakume Abertzale Batza (Agrupación de la Mujer Patriota), de Euzko Gaztedi (Juventud Vasca) y de Euzko Gastetxu Batza (Federación de Niños Vascos), así como todo tipo de entidades folclóricas. Tal y como indica Tápiz, las organizaciones paralelas son «aquellas que contribuyen a abarcar toda la vida del militante, hacer que gire, de alguna forma, en torno al partido. Este tipo de organizaciones mantienen enlaces con la formación política más o menos difuminados, pero conocidos; y con una exigencia política, en principio, menor, lo que hace que mucha gente que no siente de manera vital las exigencias de un partido, o que no está de acuerdo con algunos puntos del mismo, se acerque al calor de éste» ${ }^{51}$. La importancia de estas organizaciones dentro del movimiento nacionalista se aprecia muy bien en el desfile por la Gran Vía bilbaína, único filme en el que las organizaciones sectoriales jelkides aparecen ampliamente recogidas ${ }^{52}$.

${ }^{50}$ De ello también habla, aunque para el caso concreto del Aberri Eguna de Vitoria, Ramón Berriozabal, op. cit. La prensa nacionalista, como medio de comunicación básico entre el PNV y la militancia y simpatizantes, en los días y semanas previos a cada Aberri Eguna recoge ampliamente buena parte de las tareas organizativas empleadas para cada celebración.

51 José María Tápiz, op. cit., p. 341.

52 En el de San Sebastián no sabemos si aparecieron, pero es muy probable que fueran recogidos por las cámaras. 
Comenzamos por los mendigoxales. De ideología sabiniana radical, tuvieron gran fuerza en Vizcaya y Guipúzcoa y su papel fue clave en la República en la difusión del ideal jeltzale por las zonas más inaccesibles del país, en la realización de labores de «seguridad» (llegando a tener la apariencia de organización paramilitar) y como organizadores de los eventos del partido ${ }^{53}$. Si bien los vemos en gran número en el primer Aberri Eguna (en labores de organización y «escolta», como sabemos), no aparecen tanto en el filme de Vitoria, y desaparecen completamente en Aberri Eguna en Iruñea, debido a que la mayoría de estos, sobre todo en Vizcaya, se separaron del PNV en mayo de 1934 (críticos con la moderación política de los líderes del partido durante la República).

Por su parte, Emakume Abertzale Batza, fundada en 1922 e inspirada en el Cumann na mBan irlandés, también cobró gran protagonismo en la República, siendo la organización femenina de un partido político más importante de España ${ }^{54}$. Su influencia puede observarse en Aberri Eguna en Bil$b a o$, donde un substancial grupo de ellas marcha en un lugar privilegiado del desfile, justo detrás de los líderes históricos que abrían la marcha y a las que la cámara presta especial interés cuando pasan delante de ella. Puede vérselas muy elegantemente vestidas y portando grandes banderas de su organización. Emakume Abertzale Batza fue una de las grandes protagonistas de la jornada. Su presencia fue proporcional a la importancia que el PNV otorgó a la emakume (mujer) en la labor proselitista y protectora jelkide, en el día a día, en la vida social y familiar, aunque la despojaron de capacidad para participar activamente en política. De ahí que no se vea ninguna mujer entre los altos mandatarios jeltzales, pese a que en los Estatutos de 1933 se reconociese «la igualdad de derechos entre hombres y mujeres en la estructura organizativa del partido» ${ }^{55}$. Por último, Euzko Gastetxu Batza, Euzko Gaztedi y las numerosas organizaciones folclóricas, que son profusamente representados en todos los documentales, estaban encaminadas a ir completando la construcción del partido-comunidad que era el $\mathrm{PNV}^{56}$.

53 Ibidem, pp. 351-363.

54 José Luis de la Granja, Nacionalismo y II República en el País Vasco: Estatutos de autonomía, partidos y elecciones: Historia de Acción Nacionalista Vasca, 1930-1936, Siglo XXI, Madrid, 2008 (1. a ed. En 1986), pp. 339-340.

55 Leyre Arrieta Alberdi, «Emakume», en Santiago de Pablo et al., op. cit., 2012, pp. 207-211; José María Tápiz, op. cit., pp. 363-365.

56 Sobre el universo de las organizaciones paralelas del PNV, véase: José María Tápiz, op. cit., pp. 342-386. 
Particular relevancia cobraron las manifestaciones folclóricas de todo tipo, tanto en actos oficiales como extraoficiales, en las que participaban muchos niños y jóvenes, pertenecientes bien a Euzko Gastetxu Batza, a Euzko Gaztedi o, sencillamente, a alguna de las muchas federaciones folclóricas vascas impulsadas por el PNV. Y es que en aquella época este partido era prácticamente la única fuerza política que dio impulso al folclore vasco (símbolo vivo, para el nacionalismo vasco, de las esencias nacionales, más allá del mero folclorismo y pintoresquismo que le otorgaban las otras fuerzas políticas), particularmente a las danzas. De hecho, muchas organizaciones de dantzaris mantenían vinculación más o menos estrecha con el PNV, aunque existían otras simplemente vasquistas, no integradas en la comunidad nacionalista. Agrupaciones de todas las regiones vascas se unían ocasionalmente para hacer grandes concentraciones folclóricas, como era el caso de los Aberri Eguna, bien participando en desfiles (como vemos en Bilbao) o interpretando danzas de diferentes comarcas de Vasconia, como advertimos en Vitoria y Pamplona. Hay que destacar en esta última el gran interés mostrado por Ugartechea hacia el folclore, tanto en los actos oficiales desarrollados en la plaza de toros (donde también se fija, aunque se aprecia vagamente, en los versos recitados por unos bertsolaris), como en las danzas, que también son interpretadas por un grupo de amigos fuera de los actos oficiales, en un ambiente «familiar», lo que da idea del apego de las bases del PNV hacia el folclore vasco, por encima de su empleo político en los actos oficiales.

También hay que destacar el perfecto orden, disciplina y respeto con los que se desarrollan todos los eventos mostrados en las películas. El PNV, a través de sus múltiples medios de comunicación, fundamentalmente prensa, se afanó en notificar a sus militantes y simpatizantes la imperiosa necesidad de que todas las celebraciones transcurrieran ya no sin incidentes, sino en el mayor de los respetos. Se trataba de mostrar la civilidad, disciplina, cohesión y fuerza de un «partido de orden» como PNV, así como el «carácter pacífico» de los vascos, tantas veces subrayado por los ideólogos nacionalistas. Esto era especialmente importante en las concentraciones de Vitoria y Pamplona, donde eran sabedores de que muchos recibían con hostilidad sus ideas. Era preciso, pues, ya no sólo hacer una demostración de fuerza, sino también de respeto y de orden.

También el gobernador civil de cada provincia en la que se organizaron las fiestas estaba interesado en que todo transcurriera con normalidad, por lo 
que desplegaron a las fuerzas de seguridad en las zonas donde se desarrollarían los actos en cada ocasión. Pero, dado que los filmes trataban de mostrar la fuerza y la unidad de la comunidad nacionalistas, las fuerzas de seguridad sólo fueron recogidas por la cámara en Vitoria, donde se ve una veintena de policías en unos camiones, rodeados por los nacionalistas que llenan la calle. Los uniformados que se ven en algunas tomas en las calles de Pamplona no formarían, sin embargo, parte del dispositivo policial desplegado para la ocasión, sino que más bien son soldados que estaban haciendo el servicio militar en Pamplona y que pasan casualmente delante de las cámaras.

No menos importante en estos actos fue el homenaje a los mártires de la patria, a aquellos que sacrificaron una parte de sí mismos o sus vidas como acto de afirmación del amor patrio. Estos mártires fueron instrumentalizados durante la República con un importante valor didáctico, subrayando que su lucha no era en vano y situando su valiosa aportación en un marco de largo recorrido de la histórica lucha jeltzale por la redención de Euzkadi. En la filmación del Aberri Eguna de San Sebastián la figura del héroe-mártir está encarnada en Francisco Idiakez, en la que se le rinde un deliberado homenaje. Acusado de haber matado a un republicano en Guetaria, el tribunal lo condenó a prisión porque el jurado popular, pese a ser partidario de su absolución por actuar en defensa propia, respondió incorrectamente por su deficiente conocimiento del castellano. El caso fue muy seguido por la prensa nacionalista, que elevó a Idiakez a «símbolo de la patria» y expresión de la lucha del pueblo vasco por su honor y libertad, capitalizando el caso para condenar la anormal situación del uso del euskera en las instituciones públicas y elevándolo a la categoría de referente a seguir ${ }^{57}$. El PNV recordó y mostró sus respetos a este jelkide en el Aberri Eguna de San Sebastián, recogido en el filme Euzkadi, donde se debía ver a los vaporcitos pasando frente a la prisión de Ondarreta (en la que Idiakez estaba preso) al tiempo que sonaba el Agur jaunak, una melodía popular vasquista empleada al mismo tiempo a modo de salutación o despedida ${ }^{58}$. Así, Idiakez se sumaba a la larga lista de nacionalistas que fueron represaliados, siguiendo la estela de Sabino Arana (multado y encarcelado en numerosas ocasiones), que eran considerados mártires de la causa por sus militantes.

57 José Luis de la Granja, op. cit., 1986, pp. 341-342; El Día, 24-II-24; Euzkadi, 28-XII-1933, pp. 1-2.

58 Jesús Casquete, «Agur Jaunak», en Santiago de Pablo et al., op. cit., 2012, pp. 85-89. 
En el desfile del Aberri Eguna en Bilbao también se puede observar a otro mártir, si bien pasa inadvertido a día de hoy, pues la cámara no se detiene en él expresamente, posiblemente captó la atención de los jeltzales que vieron la película en la República. Se trata de Federico Ugarriza, un jelkide que fue bastante conocido porque, cuando prestaba servicio como mendigoxale en Lujua en las elecciones del 12 de abril de 1931, en un enfrentamiento con los hombres armados de un «cacique» local, una bala le hizo perder la vista ${ }^{59}$. En el desfile se le puede ver, una vez pasadas las mujeres de Emakume Abertzale Batza, en la primera fila de un grupo que porta las banderas de Sabin Etxea y de todos los batzokis que acudieron al acto. Se le distingue porque lleva unas gafas para invidentes, porta una ikurriña y es guiado por dos compañeros que le agarran de los brazos. La prensa nacionalista no dudó en tomarlo como referente y «símbolo» nacional ${ }^{60}$.

No podían faltar las numerosas banderas, colgaduras y otros símbolos materiales nacionalistas que se despliegan por doquier: la ikurriña (bandera nacionalista creada por Sabino Arana para Vizcaya, pero empleada enseguida para el conjunto de Euzkadi) era un claro exponente de las aspiraciones soberanistas y religiosas del PNV ${ }^{61}$. Dada su trascendencia, no es extraño que la ikurriña sea el símbolo más repetido en todas las filmaciones, salvo en la concentración de Pamplona en la que, como ya hemos comentado, fue prohibida por el gobernador. Asimismo, en Vitoria pueden verse las banderas de los mendigoxales, con la cruz de san Andrés, santo en cuyo día, el 30 de noviembre, se habría librado la mítica batalla medieval de Arrigorriaga (que dio origen, según Arana, a la independencia de Vizcaya ${ }^{62}$. El lauburu sólo se aprecia en Pamplona, posiblemente ante la imposibilidad de usar símbolos con un mayor contenido político. Se trata de una cruz gamada curvilínea de carácter ornamental, originaria del territorio vasco en los siglos XVI-XVII, pero empleada por el PNV como un símbolo identitario de lo vasco a partir de 1934 (para evitar

59 Ramón de Galarza, «Federico de Ugarriza. «El ciego por la Patria». Las Elecciones Municipales del 31», Euzkadi, n. ${ }^{\circ}$ 120, 22-III-1979, p. 27.

${ }^{60}$ Aberri Eguna... op. cit., p. 62; Euzkadi, 18-I-1934, p. 11.

${ }^{61}$ La identificación de la ikurriña con el PNV hizo que ANV tratara de marcar cierta distancia respecto a ella, creando su propia bandera, que sin embargo tenía los mismos colores. Jesús Casquete y José Luis de la Granja, «Ikurriña», en Santiago de Pablo et al., op. cit., 2012, pp. 508-513.

62 José Luis de la Granja, «Batallas de Arrigorriaga y Munguía», en Santiago de Pablo et al., op. cit., 2012, pp. 187-202. 
emplear la cruz gamada rectilínea que empleaba Sabino Arana, muy parecida a la que con posterioridad usarían los nazis, que alcanzaron el poder en Alemania un año antes) ${ }^{63}$. Por último, el Zazpiak-bat, escudo que simboliza el anhelo político de unificar los siete territorios vascos, se ve en la balconada del batzoki de la Plaza de la República de Vitoria. De este modo, las filmaciones de la época se convierten en fuente y testigo del andamiaje simbólico utilizado por el PNV en la etapa republicana para movilizar a sus afiliados y simpatizantes.

En todas las películas, estos símbolos aparecen en muchos formatos y cuelgan de diversos edificios, muchos de los cuales aparecen delante de la cámara como parte de los actos oficiales del día o del atrezzo festivoreivindicativo, pero en no pocas ocasiones es el propio cameraman quien los busca y plasma intencionadamente. Esta intención la vemos en Sabin Etxea (edificio que se convirtió desde la muerte de Sabino en un símbolo en sí mismo para los jeltzales) ${ }^{64}$, el cual aparece engalanado con colgaduras con los colores nacionales y una gran ikurriña ondeando en un asta, en la que la cámara se detiene; o en el Centro Vasco o batzoki de Vitoria donde se hace un plano general de la balconada, donde hay todo un elenco de banderas y símbolos nacionalistas. También se observa, sin que la cámara se detenga en ellos expresamente, que son portados por muchas personas: nacionalistas anónimos, líderes históricos en el desfile de Bilbao, miembros de las organizaciones paralelas del partido, los miembros de las comisiones organizadoras (con brazalete), etc. En el desfile de Bilbao, algunas banderas cobran una especial significancia, como la «antigua bandera juradera», portada por el prestigioso nacionalista Rafael de Mendiguren, o la bandera de la primera entidad nacionalista, llevada por Luis Arbeloa, otro histórico afiliado al PNV, enlazando así con el homenaje tributado a Sabino Arana ${ }^{65}$.

No se observa, sin embargo, casi ninguna bandera ni símbolo nacionalista en Aberri Eguna en Iruñea. Como ya hemos adelantado, las autoridades públicas ordenaron la prohibición de exhibir símbolos políticos de corte nacionalista, orden que el PNV se afanó en cumplir. Solamente se ve una ikurriña en la plaza de toros, cuando se están desarrollando los

63 Santiago de Pablo, «El lauburu. Política, cultura e identidad nacional en torno a un símbolo del País Vasco», Memoria y Civilización, 2009, n. ${ }^{\circ}$ 12, pp. 109-153.

${ }^{64}$ José Luis de la Granja, «Sabin Etxea», en Santiago de Pablo et al., op. cit., 2012, pp. 674-684.

65 Aberri Eguna... op. cit., p. 63. 
actos de la tarde en medio de un desfile folclórico. La decisión de exhibir su bandera nacional en este tardío momento de la fiesta, con toda seguridad fue un intento simbólico de mostrar la rebeldía frente a la prohibición gubernamental, con la precaución de haberlo hecho una vez hubieran transcurrido los actos centrales del día, evitando así la posible cancelación de los actos. La fijación de Ugartechea en este momento tan puntual dentro del conjunto de la fiesta, revela la importancia que él mismo y el PNV confirieron a la exhibición de la ikurriña, que según recogió el diario Euzkadi, fue aclamada por toda la plaza ${ }^{66}$. Sin embargo, el PNV no se conformó sólo con esto. Y es que ante la imposibilidad de usar símbolos nacionalistas más políticos, el PNV desplegó por primera vez el símbolo del lauburu de forma sistemática, convirtiéndolo oficialmente en el «distintivo del Euzkadi-Eguna» ${ }^{67}$ y difundiéndolo por doquier. Así, podemos ver el lauburu en el centro de cada balconada de la plaza de toros y, aunque las cámaras no lo aprecian dada la escasa calidad de las imágenes, también se usó en las pegatinas que se observan en las solapas muchos líderes y simpatizantes nacionalistas.

La anormalidad del desarrollo del Aberri Eguna de Pamplona se observa también en el diferente uso de los espacios públicos respecto al resto de celebraciones, en las que no hubo prohibiciones espaciales tan severas. Mientras que en los tres primeros Aberri Eguna se aprecia que existe plena libertad para la pública manifestación de la fiesta, en el que se aprovechan espacios tan céntricos como simbólicos (particularmente en el de Bilbao), en Pamplona se observa cómo los únicos actos políticos mostrados se celebran en el interior de la plaza de toros, mientras que las pocas tomas exteriores mostradas carecen de connotaciones explícitamente políticas.

La presencia de líderes y dirigentes del PNV también ocupa una parte destacada en los filmes. Absteniéndonos de hacer una mera descripción de las personalidades que aparecen, queremos detener nuestra mirada en un aspecto muy concreto, el de cómo las películas son una herramienta complementaria para observar el cambio de liderazgo políticodoctrinario que se estaba empezando a vislumbrar en el partido durante la República (del radicalismo al moderantismo, del aranismo a la democracia cristiana). Antes del inicio de la II República, la Asamblea de

\footnotetext{
66 Euzkadi, 02-VII-1935, p. 5.

67 Euzkadi, 30-VI-1935, p. 3.
} 
Bergara de 1930 fijó la doctrina del PNV en los principios del aranismo, permaneciendo inalterables por el resto de la República. Este predominio del aranismo se vio reflejado claramente en el significado del primer Aberri Eguna, en el control político de los consejos regionales y el consejo nacional por parte de los aranistas (Luis Arana fue presidente del Euzkadi Buru Batzar -Consejo Nacional del PNV - entre 1932 y 1933) y en la publicación durante toda la República de todo tipo de artículos, obras y biografías de y sobre Arana. Sin embargo, en estos años comenzó a aparecer una nueva generación de nacionalistas, que se inclinaron hacia la democracia cristiana y la consecución del Estatuto de Autonomía para Euzkadi, superando poco a poco los aspectos más integristas y radicales del aranismo. La cabeza visible de este grupo estuvo representada por los diputados a Cortes, sobre todo por Aguirre e Irujo, los cuales fueron ganando cada vez más prestigio entre la comunidad nacionalista e incluso entre los ciudadanos vascos con motivo del complejo proceso estatutario que se vivió desde el comienzo de la República hasta $1936^{68}$. Este cambio se manifestó políticamente en la Asamblea del partido celebrada en Tolosa (Guipúzcoa) en 1933, cuando Irujo y Aguirre se impusieron al sector aranista. De entre ellos, Aguirre fue quien mayor proyección tuvo, al ser el líder del movimiento de alcaldes por la autonomía y líder de la minoría jelkide en las Cortes, a lo que hay que sumar su gran carisma y su carácter conciliador.

Este cambio de liderazgo se observa en las filmaciones de los Aberri Eguna. Así, en Aberri Eguna en Bilbao puede verse cómo el desfile es encabezado por los nacionalistas históricos, la mayoría aranistas (entre ellos Luis Arana), lo que denota la importancia de estos en la jerarquía del partido. Por el contrario, los diputados a Cortes (entre ellos Aguirre) aparecen en una posición secundaria dentro de la procesión, en la parte central del desfile (por detrás, incluso, de Emakume Abertzale Batza). Este orden jerárquico desaparece en los siguientes filmes, en los que no encontramos rastro del sector aranista, mientras que la nueva generación de nacionalistas monopoliza la atención de la cámara: en San Sebastián y Vitoria, aparecen los diputados Aguirre y Monzón, pronunciando un discurso y posando para la cámara respectivamente; en Pamplona se pueden ver a estos mismos dos y a los diputados Irujo, Francisco Javier Landaburu y Ra-

68 José Luis de la Granja, «El Aranismo, ideología dominante del Partido Nacionalista Vasco en los años treinta: Acta de la Asamblea de Bergara», en Congreso de Historia de Euskal Herria, Txertoa, Donostia-San Sebastián, Vol. 5, 1988, pp. 459-473. 
fael Picavea, de los que pronuncian mítines los tres primeros, además de que a Monzón y Picavea se les ve amigablemente rodeados de nacionalistas antes de entrar en la plaza de toros. Pero en Pamplona se observa, además, que entre estos nuevos líderes, Aguirre adquiere un especial protagonismo, pues se le ve en la tribuna presidencial de la plaza de toros abriendo la entonación del himno vasco, secundado a continuación por toda la plaza, momento que nos es mostrado con gran interés por Ugartechea mediante una panorámica que va desde un plano medio de Aguirre, rodeado de líderes y jelkides varios, a un plano general de la plaza. Todo ello es un claro exponente del gran prestigio que adquirió durante aquellos años como líder de los diputados vascos en las Cortes y del movimiento por la autonomía.

Entre otros detalles significativos, en estas películas se aprecia la confesionalidad católica del PNV y los jeltzales. Una visión más «oficialista» es la que muestra Hernandorena en San Sebastián donde, como parte de los actos oficiales del Aberri Eguna, se celebró una misa mayor en la iglesia de Santa María, siendo recogido por la cámara el momento de la salida de la gente de la eucaristía (que había sido, además, una misa marcadamente jeltzale $\left.{ }^{69}\right)$. Más «familiar», pero de igual interés, es una escena que filma Ugartechea en Pamplona en la que se observa a un cura entre un grupo de amigos, el cual está disfrutando de las improvisadas danzas vascas interpretadas por algunos nacionalistas junto a una campa. Ambas visiones no sólo son un reflejo visual del catolicismo del PNV y de sus bases sino de cómo algunos sectores del clero vasco apoyaron a este partido, aunque también hubo otros sacerdotes que optaron por sectores políticos españolistas, al dividirse políticamente la Iglesia en el País Vasco-Navarro entre el PNV, los carlistas y otros sectores confesionales ${ }^{70}$.

También es posible apreciar en los filmes el carácter interclasista y de masas del partido, a juzgar por el gran número de asistentes y el heterogéneo tipo y calidad de las vestimentas de los miles de nacionalistas que se ven en las películas. En efecto, en la década de 1930 el PNV era un partido interclasista, con apoyos fuertes tanto en el campesinado y las

${ }^{69}$ El coro de Euzko-abesbatza interpretó interpretó el Euzko Abendearen Ereskia (himno vasco) y la Marcha de Iñaki Deuna (Marcha de San Ignacio, santo por el que Sabino Arana sentía profunda devoción).

70 Santiago de Pablo, «La Iglesia», en José Luis de la Granja y Santiago de Pablo (eds.), op. cit., 2002, pp. 299-325. 
clases medias, como entre la clase trabajadora. En esta labor jugó un papel primordial el sindicato nacionalista Solidaridad de Obreros Vascos, denominado a partir de 1933 STV-ELA (Solidaridad de los Trabajadores Vascos-Eusko Langileen Alkartasuna), que durante el período republicano pasaría a competir con el sindicato socialista UGT en la pugna por el liderazgo sindical vasco ${ }^{71}$. No obstante, resulta interesante destacar que la creciente importancia de ELA-STV no se vio explícitamente reflejada en ninguno de los Aberri Eguna estudiados, a diferencia de otras organizaciones sectoriales antes citadas que destacaron profusamente tanto en los Aberri Eguna como en las películas. En este sentido - aunque es una cuestión que merecería un estudio más profundo-, es posible que la doble militancia (en el PNV o en algunas de sus organizaciones satélites y en ELA-STV) de muchos de los afiliados del sindicato les llevara a participar en el Aberri Eguna como miembros del batzoki y no encuadrados en una ELA-STV que fue adquiriendo mayor independencia orgánica con respecto al PNV que otras organizaciones satélites.

La simbiosis entre tradición y modernidad característica del PNV desde sus orígenes tiene también su eco en estas filmaciones. Simbiosis que en muchas ocasiones se resolvía con una política simbólica y retórica que evocaba a lo tradicional y lo rural que no era óbice para realizar una praxis moderna y urbana. Esto era consecuencia en gran parte del propio surgimiento del partido jeltzale en Bilbao, pero también de lo avanzado del proceso industrial en Vizcaya y Guipúzcoa donde el nacionalismo era mayoritario. El desarrollo de estos Aberri Eguna en el ámbito de lo urbano es el principal síntoma de ello, justificado por causas tanto logísticas como simbólicas: por un lado, así se facilitaba la exhibición pública y masiva del movimiento jeltzale en un espacio poblado y, sobre todo, bien comunicado; por otro, se pasaba por lugares de memoria para el PNV, como el aludido homenaje a Arana en Bilbao. A esto hay que añadir la nada oculta intención de «revasquizar» lo urbano, considerado por Arana en su etapa radical inicial como el verdugo de la tradición y la raza euzkara. La misma utilización para usos propagandísticos del moderno medio fílmico (cuyo origen no se entiende sin la industrialización) choca con el contenido de las películas analizadas, que, pese a estar rodadas en la ciudad, hacen constantes referencias a lo rural y a lo tradicional. Sin embargo, tal

${ }^{71}$ Dario Ansel, ELA en la Segunda República. Evolución sindicalista de una organización obrera, Txalaparta, Tafalla, 2011, pp. 249-265; José María Tápiz, op. cit., pp. 365-367. 
y como ya hemos señalado, paralelamente nos muestran el uso masivo de modernos medios de transporte para llevar a la comunidad jeltzale a las concentraciones. Por no hablar de lo dispar de las vestimentas empleadas por los miles de nacionalistas que vemos en los filmes, que destacan no sólo su heterogénea procedencia social, sino su origen tanto rural como urbano. Así, las vestimentas populares de casheros y actos folclóricos, que ofrecen una imagen atemporal del País, se contraponen a las contemporáneas vestimentas burguesas de, por ejemplo, los dirigentes del partido y Emakume Abertzale Batza.

\section{Proyección e impacto}

Todas las películas, a excepción de la filmación doméstica Aberri Eguna en Iruñea descubierta recientemente, fueron exhibidas en público antes de la Guerra Civil. De ellas, Euzkadi de Hernandorena era, de lejos, la más elaborada a nivel técnico y discursivo, siendo la primera en proyectarse y la que más éxito tuvo en las salas. Estrenada en sesión privada en el Gran Teatro Kursaal de San Sebastián el día 21 de diciembre de 1933, la primera exhibición pública fue al día siguiente en el mismo local y tuvo gran éxito tanto aquí como en las localidades vascas en las que se proyectó los meses sucesivos. A finales de abril de 1934, comenzó a proyectarse como Euzkadi II, una versión «corregida y ampliada», en la que añadieron al filme original la proyección del Aberri Eguna en Bilbao, Vistas del Aberri Eguna en Gasteiz y Viaje de Euzko-Abesbatza a Barcelona $^{72}$. Este añadido seguramente no se hizo modificando la versión original, sino proyectando las otras películas en bruto $^{73}$, como meros complementos de esta antes de su proyección, siendo un recurso habitual en el cine de la época. Según Santiago de Pablo, «la película fue al parecer proyectada también en Filipinas, aunque fracasó el intento de estrenarla en Argentina, Uruguay y, probablemente, en México» ${ }^{74}$.

72 «Euzko-Araudi ukaintzea Madrid'en»y «Arana-Goiri'tar Sabin'eri Kataluña'ren omenaldia». Euzkadi, 19-V-1934.

73 Es decir, sin montar ni sonorizar, tal y como nos han llegado a día de hoy.

74 Santiago de Pablo, op. cit., 2006, p. 17. Sin embargo, era falsa la noticia aparecida en El Día el 28 de diciembre de 1933 de que una «editorial» alemana había ofrecido a Hernandorena 200.000 pesetas por la proyección en exclusiva del filme por Europa. El propio periódico reconoció al día siguiente que fue un engaño publicitario, justificado por tratarse del día de los Santos Inocentes. 
Sin embargo, el éxito Euzkadi en las salas no dejó de ser un éxito limitado. Y es que la película, más que responder a una política propagandística calculada del PNV orientada a conquistar nuevas conciencias, parece más una creación que reflejaba las inquietudes personales de Hernandorena, sin mayor propósito que el de elevar los corazones de los que ya eran nacionalistas. De hecho, esta película (así como Euzkadi II) sólo se exhibió donde el nacionalismo estaba más implantado, en proyecciones organizadas por las Juntas Municipales del PNV de las localidades por las que pasaba el filme: así, se proyectó fundamentalmente en las ciudades y pueblos más importantes de Vizcaya y Guipúzcoa ${ }^{75}$, mientras que en Navarra sólo se proyectó en Pamplona ${ }^{76}$, Lizarra $^{77}$ y Elizondo ${ }^{78}$. Un buen indicador del carácter más peneuvista que nacionalista de la cinta Euzkadi, es que sólo la prensa afín al PNV la publicitó, instando incluso a sus afiliados a verla cuando se proyectara en su localidad o cerca de ella. Sin embargo, el periódico de ANV, Tierra Vasca, tal como hicieran los periódicos no nacionalistas vascos, no dio un tratamiento especial al filme más allá de anunciarlo en Cartelera, como si de una película más se tratara ${ }^{79}$. Se trata de una prueba más de las dife-

75 Véanse los diarios Euzkadi, El Día, La Voz de Navarra y el semanario Argia desde diciembre de 1933 hasta junio de 1934 para ver las ciudades y pueblos en los que se proyectaron las películas: San Sebastián (21/22-XII-33); Hernani (23-XII-33); Tolosa (24XII-33); Bilbao (27/28/31-XII-33); San Sebastián (1-I-34); Ordicia (6-I-34); Bermeo (7-I-34); Eibar (9/10-I-34); Ordicia (11-I-34); Rentería (12-I-34); Mondragón (13-I-34); Azcoitia (14I-34); Baracaldo (19-I-34); Rentería (19-I-34); Guecho (20-I-34); Bilbao (2-II-34); Basauri 3-II-34); Lequeitio (04-II-34); Erandio (7-II-34); Guernica (17-II-34); Valmaseda (24-25/ II/34); Tolosa (i26-27?/II/34); Pamplona (28/II/34); Estella (31/III/34); Elizondo (8-IV-34); San Sebastián (30-IV-34); Eibar (8-V-34); Ordicia (9-V-34); Rentería (11-V-34); Irún (12V-34); San Sebastián (13-V-34); Oñate (19-V-34); Zarauz (20-V-34); Bilbao (6-VI-36).

${ }_{76}$ Euzkadi, 1-III-1934, p. 5.

77 La Voz de Navarra, 8-III-1934, p. 1.

78 La Voz de Navarra, 7-IV-1934, p. 1.

79 El Pueblo Vasco (diario cercano al PNV) sí hizo un tratamiento con cierta profundidad al filme en su estreno en San Sebastián. Por el contrario, La Constancia (integrista, editado en San Sebastián), sólo lo anunció en cartelera. Los diarios no nacionalistas editados en Bilbao no dieron ninguna cobertura al estreno de la película en San Sebastián, aunque cuando el filme llegó a Bilbao los días 27 y 28 de diciembre de 1933, algunos sólo lo anunciaron en cartelera (el católico La Gaceta del Norte), mientras que otros no se hicieron eco de su presencia (El Liberal, republicano-socialista; El Nervión, monárquico; El Noticiero Bilbaíno, independiente; El Pueblo Vasco, monárquico-conservador). Cuando el filme volvió a proyectarse en Bilbao el día 31 todos los periódicos lo anunciaron en cartelera. 
rencias ideológicas que tenían el PNV y el nacionalismo heterodoxo de ANV, si bien el diario peneuvista El Día (23-XII-1933, p. 1) intentó resaltar el carácter no propagandístico y netamente documental del filme, afirmando que «Euzkadi es Euzkadi». Pese a todo, tras el éxito de los primeros meses, la película entró en el olvido hasta la Guerra Civil, momento en el que la cinta desaparecería para siempre víctima de la presunta destrucción por los franquistas tras la toma de San Sebastián.

\section{Conclusión}

Las filmaciones de los cuatro primeros Aberri Eguna constituyen unos documentos fílmicos de gran valor histórico pues, contrastadas con otras fuentes, dicen mucho acerca de cómo se desarrollaron las fiestas, así cómo de la forma en que eran vistas por los jeltzales y el modo en que querían reflejarlas en las pantallas. Valor aumentado, si cabe, por el hecho de tratarse de fechas tan cruciales del calendario nacionalista, donde se exhiben y sintetizan buena parte de la simbología y emociones jeltzales.

Además de mostrarse en ellos los principales eventos desarrollados durante los Aberri Eguna, permiten profundizar en el desarrollo y organización de cada una de las celebraciones y observar el ambiente festivo y reivindicativo que en ellas se respiraba; ahondar en la historia del PNV, en su estructura organizativa, bases sociales, su evolución ideológica y su cambio de liderazgos; y analizar la evolución del uso y significado de los símbolos nacionalistas, ya sean materiales o inmateriales, durante la década de 1930. Estos últimos ocupan un amplísimo espectro que iría, por ejemplo, desde el mero hecho de manifestarse (con la peregrinación político-litúrgica que ello implicaba) hasta el homenaje a los mártires de la patria; desde la demostración de disciplina interna que demuestra el perfecto orden y respeto con que se desarrollaron los actos, hasta la manifestación de unidad en torno al deseo común de construcción nacional, independientemente de diferencias de otra clase: de género, culturales, sociales, generacionales, territoriales, etc.

Sin embargo la mirada no es neutral. El origen, el hilo argumental, la proyección y/o el impacto de las filmaciones subrayan el carácter, ya no tanto nacionalista, sino exclusivamente peneuvista de las mismas. Se presentan así como una muestra de autoafirmación jeltzale, pues exhiben y quieren exhibir la forma en que el PNV estaba construyendo su «partido- 
comunidad», como base de la «civilización nacionalista» que deseaban crear, ya que era un partido que se consideraba a sí mismo un «pueblo en marcha», con una estructura de «gobierno provisional», previo a la construcción de la futura Euzkadi.

En definitiva, las cuatro películas de los Aberri Eguna de 1932-1935 nos exponen la forma en que el PNV daba cuerpo en las calles y en el celuloide a la abstracción de la «comunidad imaginada», mediante «manifestaciones de masas organizadas de forma ritual» ${ }^{80}$, y hacía una demostración de fuerza del potencial de su movimiento, fundamental para garantizar la supervivencia del mismo en una coyuntura política clave, como fue la II República.

80 Jesús Casquete, op. cit., 2005, p. 101. 